Dossiê Amazônia brasileira I 
Estudos Avançados 19 (53), 2005 


\title{
Aziz Ab'Sáber: problemas da Amazônia brasileira
}

\author{
ENTREVISTA A DARIO LUIS BORELLLI ET AL.
}

$\mathrm{E}$

M NOME da revista ESTUDOS AVANÇADOS, gostaria de saudar a presença do professor Aziz Ab'Sáber, que acaba de acrescentar mais um tento à sua brilhante carreira de pesquisador publicando, pela Editora da USP, São Paulo, Ensaios, entreveros, um livro fartamente ilustrado, de mais de quinhentas páginas, com vinte e um textos, além de extensa bibliografia complementar, centrados em uma das maiores metrópoles do planeta, a nossa capital paulista. Ao professor Aziz os nossos cumprimentos.

Também gostaria de agradecer a presença do geólogo Gerôncio Rocha, a quem ESTUDOS AVANCADOS deve o seu mais lúcido ensaio publicado sobre o Aqüífero Guarani, e dos jornalistas Ulisses Cappozoli, Mauro Bellesa e Ana Maria Fiori, que gentilmente aceitaram nosso convite para estarem presentes nesta entrevista.

Nunca é demais dizer que, no Brasil e fora dele, poucas pessoas conhecem tão bem os problemas da Amazônia brasileira como o nosso professor Aziz Ab'Sáber. Suas pesquisas foram fundamentais para o que se convencionou chamar de a Teoria dos Refúgios e Redutos. Segundo essa teoria, durante a última glaciação, a Amazônia ter-se-ia reduzido a pequenas reservas. Seu livro Amazônia: do discurso à práxis, também publicado pela Edusp, acaba de ganhar uma nova edição, pois desperta constantemente um grande interesse entre leigos e especialistas.

A pedido da revista, o nosso entrevistado apresentou inicialmente alguns tópicos que podem nortear as discussões de hoje sobre o tema. (Dario Luis Borelli)

\section{A ordem da grandeza espacial da Amazônia}

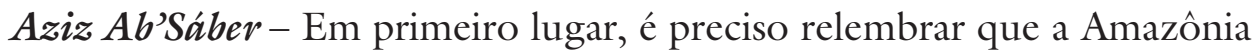
brasileira é um conjunto de paisagens e ecologias da América do Sul setentrional. Possuímos a maior parcela territorial dentro da Amazônia pan-americana.

Em segundo lugar, gostaria de destacar um fato relacionado aos diferentes domínios de natureza no Brasil. Depois de muita bibliografia, muita pesquisa, todo mundo chega à conclusão de que nós temos seis principais domínios de natureza no Brasil. Os geógrafos preferem domínios morfoclimáticos e fitogeográficos, os quais os biólogos chamam apenas de biomas - deveriam chamar de biomas continentais, mesmo porque existem zonobiomas, que são biomas que atravessam áreas muito grandes de um continente a outro e que reaparecem em continentes vizinhos. Então fica estabelecido, diante dos domínios de natureza, 
biomas continentais e zonobiomas, dos quais a Amazônia é uma parte de notável originalidade e extensão.

O problema de escala para a região amazônica é essencial: são quatro milhões e duzentos mil $\mathrm{km}^{2}$ de área, dezesseis a dezessete vezes o estado de São Paulo, com 95\% do espaço total florestado. São florestas tropicais biodiversas de grande extensão, com alguns redutos de vegetação do passado - sobretudo redutos do cerrado, em Monte Alegre (PA), Amapá, miniredutos de cerrado no meio das campestres de Roraima. Na periferia das florestas amazônicas biodiversas ocorrem transições complicadas tanto ao sul quanto ao norte do corpo principal da grande floresta.

Na minha história de pesquisas, foi a região entre o Maranhão oriental, $o$ Maranhão central e sudeste que possibilitou entender as chamadas faixas de transição e de contato. A Amazônia faz contatos muito fortes e transicionais com os cerrados e com os chapadões ocidentais do Maranhão, de modo que mais para o norte há um decréscimo de continuidade florestal. À parte disso, há um aspecto fundamental na Amazônia: todo o conjunto que fica entre a região cisandina (região interna dos Andes), até o golfão Marajoara, apresenta uma só e mesma drenagem, o que indica que a homogeneidade não está unicamente relacionada à presença de grandes extensões de florestas, mas também de uma drenagem que é como se fosse um leque, muito amplo, que fica entre a região cisandina e o começo do estrangulamento por terrenos cristalinos do planalto das Guianas e do planalto brasileiro setentrional, dando a impressão errônea de que é tudo muito homogêneo.

Então acontece um primeiro fato no qual a drenagem é sobreposta à bacia sedimentar amazônica, recebendo rios que vêm dos cerrados e altiplanos do centro do Planalto Brasileiro e rios menores que vêm do Planalto das Guianas: conjunto esse que, por muito tempo, constituiu os únicos caminhos de circulação, para homens e mercadorias.

A extensão da bacia hidrográfica favoreceu penetrações muito grandes e é provável que a colonização portuguesa que rompeu a linha de Tordesilhas norte-sul pôde penetrar pelo rio principal, o baixo Amazonas, o médio Amazonas, chegando ao Solimões, subindo até o rio Branco, impedindo a penetração dos colonizadores espanhóis que vinham pelo norte, sudoeste etc. Paradoxalmente, a drenagem foi fundamental como alongado eixo de penetração dos portugueses e isto resultou em grandes conflitos com os habitantes indígenas regionais, o que representou uma história bastante trágica.

Um outro problema é que a drenagem, em seu conjunto, é uma só, mas as águas dos rios afluentes são diferenciadas, e, às vezes, com diferenças gritantes. Existem rios brancos, com grande carga de sedimentos argilosos; há os negros, com quase nenhuma carga de sedimentos argilosos em solução, e também os brancos, em cima de areais transportados a partir da bacia sedimentar de Boa Vista, em Roraima, percorrendo grande trecho do chamado "lavrado" - que é o 
nome que se dá para esta área dos campestres de Roraima, com os arenosos campestres sobre areias. Conheço isso duplamente porque estive lá num período de grandes queimadas e o rio ficou muito baixo, e apareceram montes fantásticos de areias no leito seco do rio com dois canaletes laterais.

Isto posto, interessa-nos falar um pouquinho da nomenclatura que o povo dá para esse conjunto de regiões. Na Amazônia predominam dois termos genéricos de aplicação de corrente popular e cotidiana: a "terra firme" e a "várzea". Do ponto de vista científico, a terra firme não é igual em toda parte, tendo grande continuidade e homogeneidade nos tabuleiros ondulados da Amazônia e modificações setoriais em diversos pontos devido ao contraste nos solos aflorantes. Às vezes, aparecem pequenos setores onde se verifica a existência de muita areia e onde a floresta não entra: campinas, campinaranas e réstias de cerrado em terraços arenosos.

O fato de que a floresta tem um pano de fundo geral e que localmente possa ter algumas espécies e subespécies diferenciadas levou o professor Jürgen Haffer (um geólogo alemão categorizado que percorreu várias partes da Amazônia sulamericana, fazendo estudos geofísicos para uma possível descoberta de petróleo) a realizar estudos complementares nas clareiras da floresta. Haffer, em todas as clareiras nas quais parou na Amazônia sul-americana, anotou todos os pássaros que aparecem na Amazônia ombrofílica (floresta de sombra), que é a principal do conjunto das matas tropicais biodiversas da Amazônia, chegando à conclusão de que em vários lugares havia algumas espécies diferentes do conjunto amazônico e que, para ser explicado, ele teria que utilizar a interpretação de que o manto florestal não foi totalmente contínuo em certos momentos do período quaternário, e que eventualmente houve predominância maior de cerrados, separando em malha complicada os restantes setores de florestas. Com isso, ele chegou à Teoria dos Refúgios (1969), enquanto eu e Vanzolini, por outros caminhos da ciência, chegamos à Teoria dos Redutos e Refúgios (1960-1970). A observação do professor Haffer partiu do conhecimento da distribuição dos pássaros dentro do gigantesco espaço territorial da Amazônia. As observações feitas em São Paulo partiram do fato de que nós já conhecíamos bem os problemas do quaternário terminal entre o Pleistoceno superior e o Holoceno. Sabíamos que entre 23 mil e doze mil anos, tendo como ponto de partida observações fundamentais de Jean Tricart e André Cailleux, houve num certo momento a penetração de caatingas em muitas depressões interplanáuticas do centro-sul do território brasileiro; de forma que, em algum período do quaternário, o domínio das caatingas deve ter se estendido por muitos setores do planalto brasileiro, talvez envolvendo o planalto central, até provavelmente a região do Pantanal e descendo para vários outros pontos. Nós ajudamos o professor Tricart a percorrer áreas aqui, e, em 1957, ele me disse: “Aziz, essa linha de pedras que está abaixo do solo representa provavelmente um chão pedregoso do passado, você conhece o sertão nordestino e sabe que há toalhas de cascalho no meio das caatingas". 
Quando ele falou sobre a paleoecologia, afirmou que provavelmente houve a chegada de cerradinhos ou caatingas - mas, na realidade, são diversos tipos de caatingas, como pudemos estabelecer posteriormente.

Em um trabalho recente (São Paulo: Ensaios, entreveros, 2005), fizemos referência sintética à importância dos estudos pioneiros de Cailleux e Tricart, nos seguintes termos:

A grande lição que fica desses fatos todos - em uma homenagem para Tricart e Cailleux - é a de que a ciência começa sempre com a descoberta, baseada em observações detalhadas e cuidadosas; enquanto a interpretação dos fatos observados, para ser válida, depende de conhecimentos comparativos de áreas diversas e de tempos diferentes, assim como do uso de eventuais instrumentos registradores ou amplificadores. Do cuidado nas observações e da multiplicação de trabalhos analíticos pode-se chegar a teorias sedutoras. E das teorias pioneiras e corretamente elaboradas é que foi possível atingir inesperados conhecimentos. Sobre os ombros das interpretações de Cailleux e Tricart atingiu-se, pelo estudo de áreas-chave, o conhecimento dos palimpsestos paisagísticos de ordem regional ou sub-regional.

É interessante lembrar que, para restaurar parte da sucessão de quadros ecológicos no quaternário do Brasil oriental, Tricart baseou-se fundamentalmente na ocorrência de stone lines em diferentes locais das subáreas regionais. No caso da Amazônia, porém, onde por grandes espaços predominam rochas sedimentares (Formação Barreiras e Alter do Chão) não ocorriam sinais de chão pedregoso do passado tão visíveis quanto aqueles encontrados nas depressões intermontanas e interplanálticas do leste-sudeste e sul do país. No entanto, a presença de crostas limoníticas eventuais na estrutura superficial de alguns setores da Amazônia, segundo pudemos constatar, revelava um outro padrão de linhas de fragmentos de tempos mais secos localizados. Por outro lado, nos morros florestados do Amapá foram encontradas fragmentárias linhas de pedras que exigiam interpretações mais seguras; além disso, foi possível entender os enclaves de cerrados existentes em Porto Alegre, no Amapá, e em terraços arenosos eventuais numa categoria similar à de redutos recentes envolvidos por uma floresta que se estendeu qualescentemente por grandes espaços dos tabuleiros e baixos platôs da Amazônia. Afora isso, muitas campinas parecem ter se implantado a partir de antigas veredas arenosas (ariscos); e o mesmo parece ter acontecido também com alguns setores das chamadas campinaranas que hoje invadiram terraços arenosos. E, por fim, existem sérias questões na transição dos campestres do lavrado com as primeiras grandes matas no centro-sul da Roraima, onde baixos pontões rochosos apresentam rupestre-biomas de cactáceas de múltiplas espécies. Nessas áreas, talvez se possam identificar um dia as etapas dos paleoclimas e paleoecologias que se processaram a partir de climas secos para cerrados e campestres e, por fim, grandes matas.

$\mathrm{Na}$ Amazônia, o problema dessas stone lines foi intensivamente estudado por mim. Encontrei algumas na região centro-ocidental de Roraima, mas não 
tinham muita continuidade e dentro das colinas da Formação Barreiras, a que se chama Formação Alter do Chão, existem sinais de que algumas crostas mais duras também participaram do chão pedregoso do passado na Amazônia.

De qualquer maneira, não houve um clima tropical constantemente úmido na Amazônia durante este último período glacial, então eu sugeriria atenção para um mapa que fiz há muito tempo, em que os cerrados predominaram e as florestas se reduziram, mas não em manchas pequenas como aqui no sudeste. É nesse ponto que entra a questão da Teoria dos Refúgios. É claro que a floresta se reduziu enquanto os cerrados se ampliaram, mas, como disse Vanzolini: "na medida em que se tem certeza na redução das florestas, pode-se entender que as matas se reduzem e uma parte da fauna se refugia". Eu acho fantástico isso, foi a nossa contribuição para a Teoria dos Refúgios; eu trabalhei com a questão dos redutos e o professor Vanzolini com a parte dos refúgios. Faço questão de destacar isso porque muita gente acha que eu sou autor da Teoria dos Refúgios mas, pelo contrário, foi somente utilizando o conhecimento de alguns pensadores pioneiros que se dedicaram ao estudo dos paleoclimas inter e subtropicais brasileiro que eu pude estabelecer essa questão da fragmentação da tropicalidade, com diminuição das florestas e ampliação dos cerrados ao norte e caatingas em vastas áreas do Brasil Tropical Atlântico.

É necessário dizer que 95\% das terras amazônicas são terras baixas, ora semiplanas, ora semi-onduladas, formando um vastíssimo conjunto de colinas. O Amazonas começa no encontro das águas e vai até o golfão Marajoara; o Solimões à montante, até a fronteira com outros países. A somatória de todas as planícies aluviais embutidas nas colinas abrange de 3 a $5 \%$ do espaço total amazônico. Isso quer dizer que 95\% dos espaços regionais ou são colinas ou - no caso do planalto das Guianas e do planalto brasileiro setentrional (área designada pelo professor Keneth Kaster como Austro-Brasília) - são de baixos platôs, morros e cerranias interfluviais extensivamente recobertas por densas florestas biodiversas, onde ocorrem maciços bem individualizados, com florestas no entorno e cimeiras campestres localizadas (caso da Serra dos Carajás), áreas mais enrugadas, regiões de morros e pequenas serras interfluviais, em geral florestadas.

Dentro desse conjunto de colinas, morros florestados em rochas cristalinas decompostas e de eventuais serras com topo plano, às vezes, como é o caso dos Carajás, representam uma velhíssima superfície de aplainamento, onde ocorrem redutos de campestres como: catassias, bromélias e vegetação campestre metalogênica. Por que metalogênica? Porque ali a crosta superficial de mineral de ferro é tão espessa que impediu a penetração das florestas tropicais.

Quando um rio qualquer sai da serra e consegue escavar essas crostas, acontecem duas coisas: ou se formam pequenos lagos de cimeira, por causa da dificuldade de trânsito das águas, ou florestas de galerias que, lateralmente, parecem com as do Brasil central porque também têm veredas de campestres. As florestas de galerias caminham no meio dos campestres até chegar no bordo da serra, onde a floresta está presente em todas as encostas. 


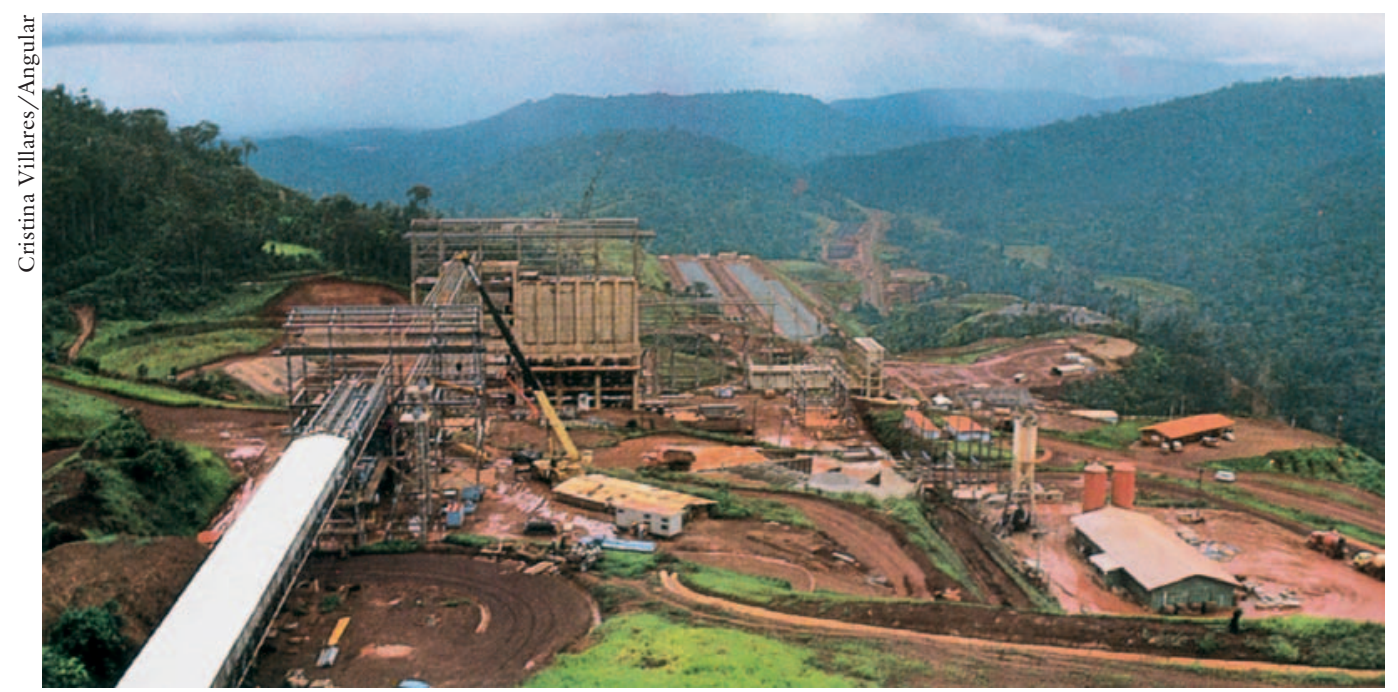

O campo de extração de minério de ferro em Carajás.

\section{O problema da fertilidade dos solos}

As planícies regionais do Solimões e do Amazonas possuem um dédalo de lagos, diques marginais, velhas restingas, velhos meandros com um pouco de areia em forma de restingas alongadas. Trata-se de um dédalo de lagos de diferentes tipos, alguns meio redondos e outros meio paralelos aos volteios de antigas restingas que ficam no centro da planície. O povo há muito tempo descobriu a fertilidade dos solos dessas planícies, assim como a constante possibilidade de pesca no rio Amazonas, nos riozinhos, igarapés e lagos.

Os informes sobre a Amazônia na década de 1940 possibilitavam avaliar uns quatro milhões de pessoas, dos quais dois milhões e meio moravam ao longo da planície por causa da fertilidade e da oferta de recursos. Isso me agradou profundamente saber, mesmo porque o quadro de hoje é extremamente mais complexo depois da invasão capitalista da Amazônia, a qual não foi bem estudada geograficamente, mas que a gente pode rever.

Também queria dizer que a razão de ser dessa fertilidade excepcional da planície, apesar dos dédalos dos lagos, está relacionada com o trânsito dos sedimentos que vêm desde os Andes ou pré-Andes, atravessando várias regiões de formações geológicas, sedimentares etc., e depois vão correndo e acrescentando os sedimentos de formação, retirados das pequenas barreiras, que, no caso, seriam falésias fluviais, de onde eram retiradas argilas e areias, que vão se misturando aos sedimentos que vêm de longe através de um complexo processo de comércio de sedimentação aluvial. Isso foi bem estudado e bem exposto pelo professor Wolfgang Junk, que é um dos grandes estudiosos da Amazônia.

Existe uma grande diferença entre os solos das planícies de rios afluentes e o conjunto de solos da faixa aluvial Solimões-Amazonas. Na realidade, os mais ricos solos de toda a Amazônia, que se destacam em relação aos imensos setores de solos mais pobres, constituem uma grande exceção. Convém lembrar que, apesar 
dos mosaicos de lagos, furos, igarapés e paranás-mirins, foi essa planície aluvial extensa o primeiro conjunto de solos úteis para as populações amazônidas tradicionais, por meio de cultivo tipo vazante, criação de gado bovino e pesca em todas as correntes e massas fluviais. Lembro que alguns técnicos mal preparados para entender a importância popular das chamadas várzeas amazônicas, em termos de sobrevivência de populações ribeirinhas, pressionavam empresários e governantes para fazer grandiosas plantações de arroz no espaço total das planícies. Uma proposta que demonstra uma lamentável falta de compromisso com o social regional.

Embutido em vastas áreas de tabuleiros ondulados e baixos platôs, o curso d'água do Solimões-Amazonas, através de seus transbordes atuais e subatuais, conforma uma planície aluvial de 15 a $20 \mathrm{~km}$ de largura, em média, sendo que o grande rio apresenta, ele próprio, uma largura de 4 a $5 \mathrm{~km}$, de forma que entre a largura do rio e a extensão lateral das planícies existe uma relação de apenas um para quatro, ou, eventualmente, um para seis. Portanto, aquilo que o povo da Amazônia chama de várzea, não é tão largo e tampouco homogêneo devido ao dédalo de lagoas, furos, igarapés e paranás-mirins.

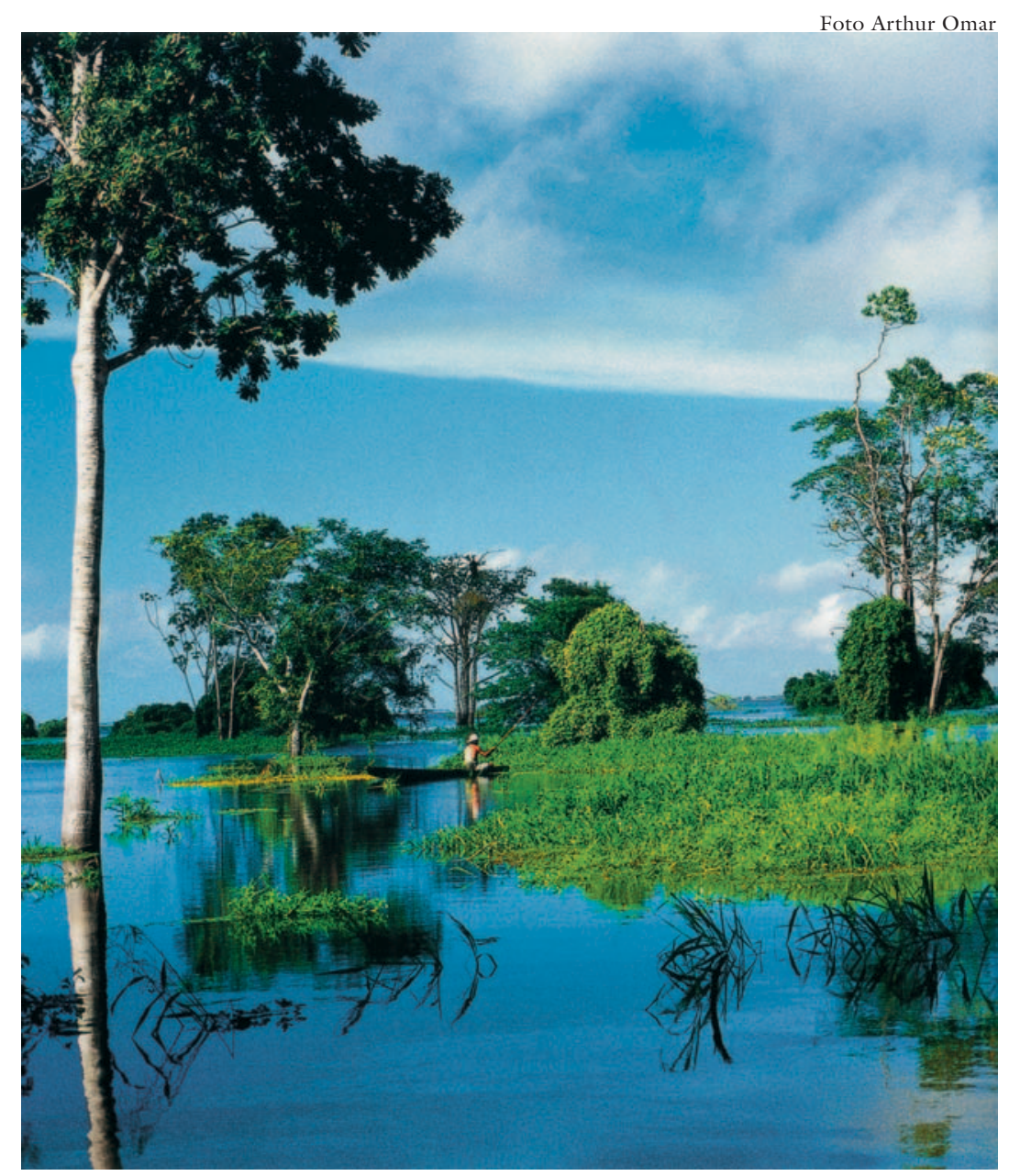

Paisagem criada com a cheia das águas do rio Amazonas. 
A partir do encontro das águas entre os rios Negro e Solimões, a sudeste de Manaus, pode-se ter uma idéia precisa da massa de argila carregada pelo SolimõesAmazonas. Trata-se, evidentemente, do curso d'água que transporta o maior volume de argilas dissolvidas em suas águas lodosas, conhecidas no mundo inteiro. Causa estupefação a dinâmica do atrito das águas do rio Negro, completamente destituído de sedimentos argilosos em dissolução. Muita coisa ainda precisa ser estudada no que tange à limpeza das águas escuras do rio Negro, sendo de se notar os componentes biogênicos e bioquímicos, que têm até hoje um papel importante na eliminação da poluição hídrica derivada da cidade de Manaus.

Enquanto o rio Solimões-Amazonas desce da região pré-andina até o golfão Marajoara sem qualquer acidente em seu leito, muitos dos rios afluentes apresentam alinhamento de quedas entre o seu largo-baixo vale e o seu médio curso. Pedro Moura, geólogo que trabalhou por dois anos no baixo Amazonas, foi o primeiro pesquisador a identificar uma linha de quedas (fall line) entre o baixo e o médio vale dos rios Tocantins, Xingu e Tapajós. Hoje sabemos que existem quadros similares de cachoeiras e corredeiras nos afluentes da margem esquerda do Amazonas, assim como após extensos setores de alguns rios da Amazônia ocidental. A gênese da fall line nesses diferentes setores, mais próximos ou mais distantes do grande rio, dependeu de flutuações no nível do mar por movimentos ditos glácio-eustáticos ocorridos nos fins do quaternário e início do holoceno. Enquanto os mares perdiam nível, rebaixando-se e descendo pela plataforma continental, o paleo-rio Amazonas da época foi forçado a realizar uma erosão regressiva que entalhou colinas e baixos platôs, mas não conseguiu estender-se pelo contato dos terrenos cristalinos resistentes, que bordejavam a bacia sedimentar amazônica. A erosão remontante de talvegue, por seu turno, deve ter sido realizada em um contexto de menor pluviosidade relativa devido à implantação natural de climas tropicais, a duas estações, conforme se deduz pela Teoria dos Redutos e Refúgios. De tal forma que, quando o rio se estendia na plataforma e adentrava no talvegue, deveria ter existido um outro quadro hidro-geomorfológico que restou tamponado e escondido pelo volume e extensão das planícies aluviais. $\mathrm{O}$ adentramento lateral de tais processos de erosão regressiva foi bloqueado no contato de rochas cristalinas e rochas sedimentares, onde se formaram as cachoeiras e corredeiras das chamadas fall lines sul-amazônicas. À medida que o nível do mar subiu muito e ficou a mais de três metros de seu nível médio atual, e que as precipitações amazônicas se tornaram maiores e mais extensivas, águas do Amazonas e Solimões afogaram o baixo vale de inúmeros rios da Amazônia, criando baías de ingressão fluvial parecidas com estuários, às quais Francis Ruellan, em uma interpretação pioneira e muito adequada, designou por "rias de água doce".

Convém registrar que a existência dos setores de cachoeiras e corredeiras da fall line conduziu a uma tentativa de solução para o transporte fluvial dos rios regionais por meio de um transbordo por pequenas ferrovias contornantes. Tais pequenos projetos rasgando trechos das selvas foram introduzidos por enge- 
nheiros ingleses que, nos fins do século XIX, já haviam tentado implantá-los em alguns setores da África. Sabe-se que esse tipo de projeto foi tentado na região de Tucuruvi e muito além, no rio Madeira, para tornar possíveis relações de transporte entre o Mamoré e o próprio grande rio Madeira (a famosa Mad Mamoré).

Convém registrar que a cachoeira de Santo Antônio, entre o baixo e o médio Jarí, é um ponto de uma fall line menos visível em rios afluentes provindos do Planalto das Guianas. E, além disso, que São Gabriel da Cachoeira, no médio-alto vale do rio Negro, constituiu outro ponto de fall lines dos rios afluentes da margem esquerda do Solimões-Amazonas.

No que concerne às terras firmes, a qualidade do solo para fins de atividades agrárias e agropecuárias é muito diferente. O solo foi formado por uma evolução integrada da floresta e de todos os seus componentes: os herbáceos, os subarbustivos e as grandes árvores etc. De tal maneira que o solo que a floresta engendrou não tem nada a ver com o solo que os agricultores pensam que vão encontrar quando devastam as florestas e queimam as toras para tentar fazer alguma agricultura. Nunca deu certo a agricultura extensiva, então os proprietários de terra entraram no domínio da agropecuária e, sobretudo, da pecuária mesmo. E isso é um problema muito sério porque os proprietários que compraram terras por preços aviltadíssimos na Amazônia dizem sempre: "agora a terra é minha e eu faço com ela o que quiser e quando quiser". Esse é o grande dilema da Amazônia em relação à destruição da cobertura vegetal para atividades ditas agropecuárias.

\section{A devastação da mata}

Com base nos registros existentes nas imagens de satélite tomadas sobre a Amazônia brasileira, pode-se detectar os diferentes caminhos de devastação que estão ocorrendo em alguns quadrantes de nossa grande região equatorial. A importância de se entender os eixos principais de degradação forçada por atividades antrópicas reside no fato de que, em certas áreas, existe uma interconexão dos processos de devastação. Por outro lado, as observações dessa intrincada malha de devastação que atinge setores da Amazônia oriental podem nos alertar sobre as conseqüências que tais processos possam acarretar, entre elas, novos caminhos de devastação provocados por especuladores insensíveis.

A região sul do Pará, entre as cidades de Marabá e a Serra dos Carajás e Serra Pelada, foi certamente a área que sofreu a maior devastação de matas tropicais em toda a Amazônia brasileira. Observações de campo realizadas na região por diversos pesquisadores, ao par com análise de imagens de satélite, podem nos oferecer um quadro lamentável da fragmentação florestal nos últimos vinte anos. Os caminhos de devastação que ali se interconectaram constituem um alerta permanente para administradores e governantes a fim de inibir a sua repetição para áreas da Amazônia onde existem ainda grandes contínuos florestais. Foi relativamente fácil a alguns de nós interpretar a conexão desastrosa das ações antrópicas incontroladas que aconteceram na região a partir da implantação da 
rodovia PA-150. Por grandes extensões do rasgão inicial produzido para a instalação da estrada que liga o sul do Pará à região de Belém, houve apropriação de terras nas duas bandas do eixo viário com retângulos de devastação de um a cinco quilômetros. $\mathrm{O}$ mesmo estilo de devastação, porém, ocorre ao longo dos chamados ramais, que são caminhos perpendiculares à rodovia. Os ramais tangentes, ou oblíquos, criam o primeiro tipo de conexão entre os espaços devastados situados entre a rodovia e o ramal. Existe, porém, um terceiro tipo de devastação nos sub-ramais, que, por sua vez, se projetam perpendicularmente aos ramais pré-implantados. Nos intervalos entre ramais, sub-ramais e rodovias foram estabelecidos espaços na forma de grandes quarteirões para serem parcelados e vendidos para quem quer que seja no Brasil. Esses quarteirões enormes rasgados por um reticulado de trilhas - designadas, devido ao seu formato, por espinhelas-de-peixe - constituíram os subespaços de mais difícil acesso no coração das matas amazônicas. Os incautos que adquiriram pedaços de terras no entorno dos ditos quarteirões raramente tiveram sucesso agrário na região, sendo obrigados a vender por preços irrisórios as madeiras nobres existentes na biodiversidade regional das florestas. Essas ditas espinhelas-de-peixe, devido à ocupação inicial predatória dos entornos dos quarteirões, acabaram por receber devastação progressiva e caótica, vindo a constituir o mais lamentável exemplo de fragmentação dos antigos espaços florestados sul-amazônicos.

Afora esses quatro tipos devastadores, ocorre a abertura de grandes espaços retangulares distantes das rodovias e ramais através de trilhas chamadas linhões, mantidas sob controle pelos proprietários devastadores. Esses produtores de "pseudo-fazendas" interiorizadas não podiam imaginar que as imagens de satélite tomadas em nível regional pudessem denunciar suas interferências incontroladas no miolo das selvas. A esses cinco caminhos de devastação sujeitos a uma interconexão progressiva, somam-se os que acontecem ao longo dos rios, riozinhos e igarapés do alto rio Guamá, que paraleliza o eixo viário sul-norte a algumas dezenas de quilômetros para leste. De passagem, diga-se que tanto os espaços de colonização oficial semiplanejados como as espinbelas-de-peixe produzidas por especuladores social e ambientalmente insensiveis conduzem ao mesmo resultado devastador atrás detalbado. O último caminho de devastação em uma faixa periférica da Amazônia é aquele evoluído desde o contato dos cerrados, cerradões e florestas pré-amazônicas, progredindo de sul para o norte, nos espaços de transição: fato denominado pela mídia de arco da devastação (norte do Mato Grosso, Rondônia, norte de Tocantins e sul-sudeste do Pará).

Julgamos indispensável o conhecimento desses processos acontecidos no sul do Pará para evitar que eles se repitam em qualquer outra área da Amazônia florestada, sobretudo no que diz respeito à Amazônia ocidental. Rasgões produzidos em qualquer subárea da Amazônia por meio de rodovias, gasodutos e eixos-viários mal planejados, certamente podem multiplicar os caminhos de devastação, centrados nos processos que vimos de analisar. 
Se nas regiões dotadas de densas áreas urbanas, sujeitas a conurbações em processo, existem perigos inauditos a diferentes profundidades de tempo, no caso da Amazônia brasileira ocorrem imensos receios relacionados com a destruição rápida e incontrolada das florestas equatoriais. Tudo porque existe total despreparo dos governantes quanto ao quadro conjuntural da região.

Parece que os governantes e seus auxiliares não sabem ler, ou têm raiva e ciúmes em face de estudos e idéias para um correto estabelecimento de políticas públicas. Era de esperar tal descalabro desde o momento em que os membros do primeiro escalão do governo transformaram as chamadas "organizações não-governamentais" em equipes robotizadas de ordem governamental.

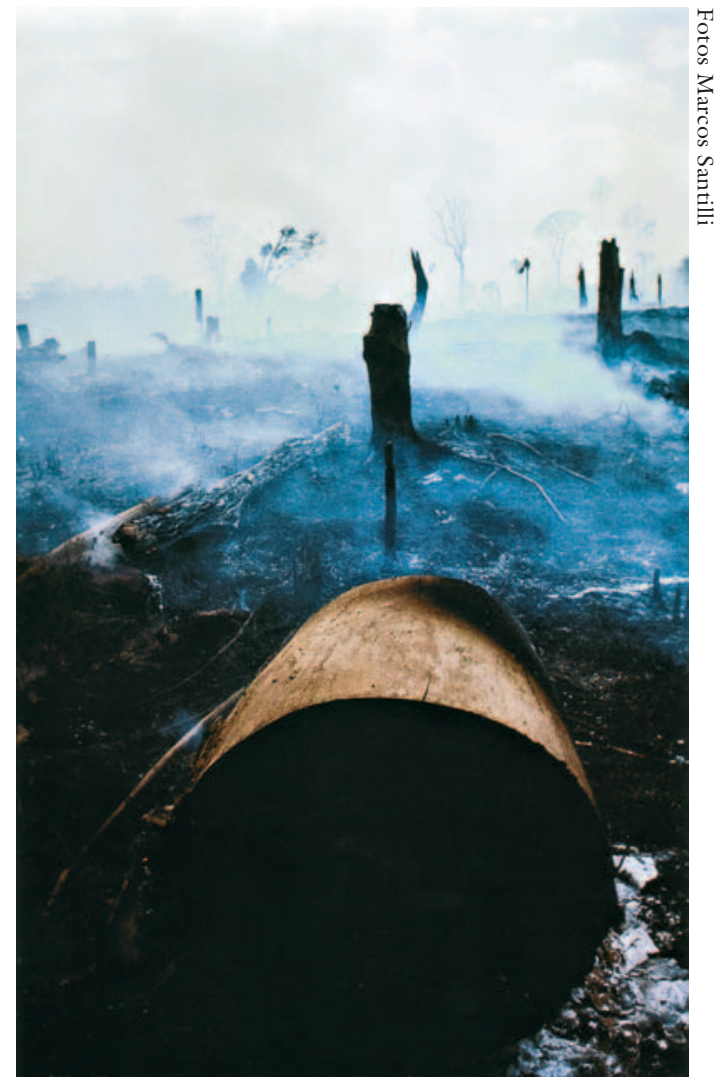

Queimada, Santa Luzia.

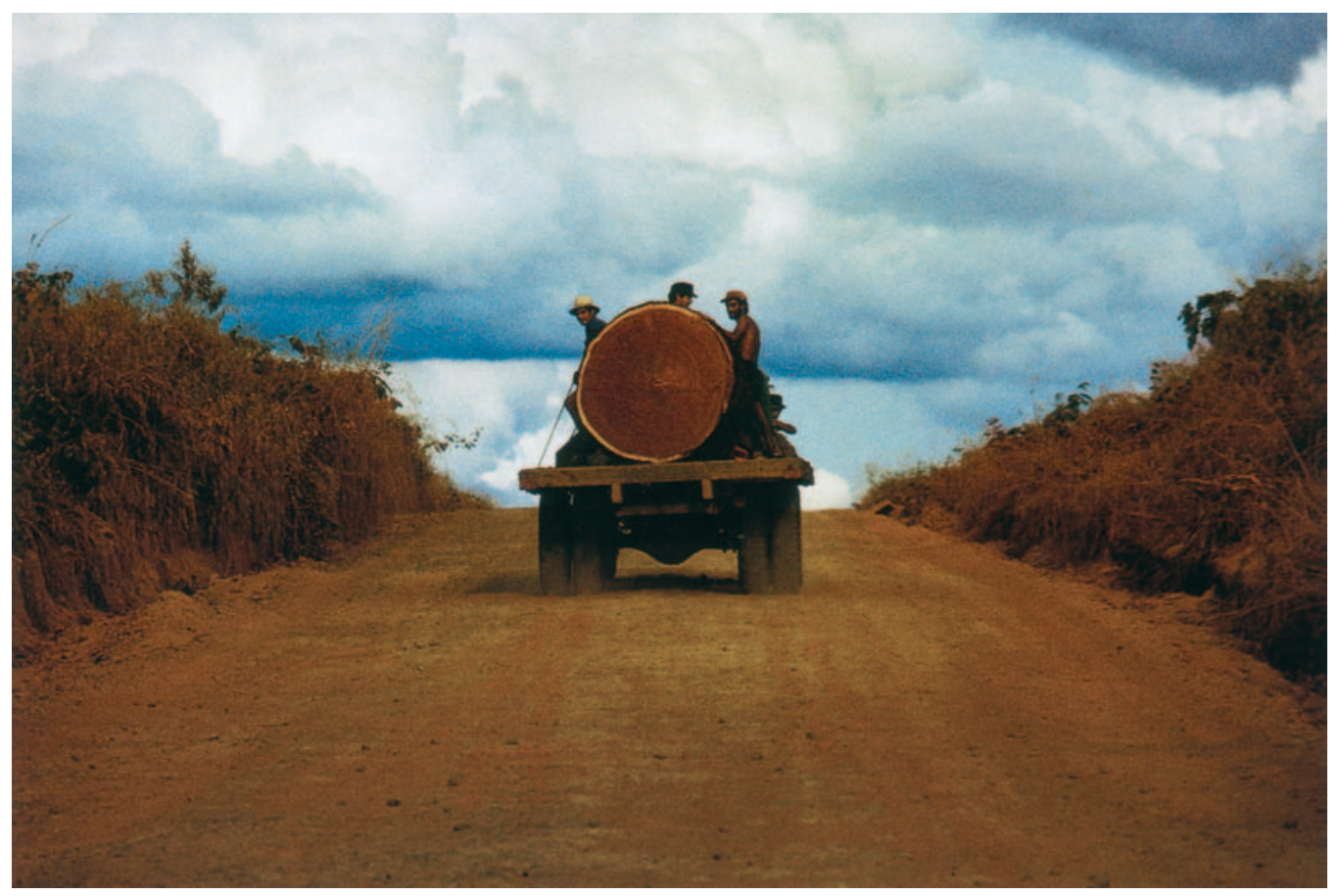

Rodovia BR 364. 
Para infelicidade do destino da biodiversidade amazônica, o mais alto dignitário da nação, através de um ato falho verbal, acenou com uma liberação inoportuna para todos os devastadores. A frase dele foi: "a Amazônia não pode ser intocável". O problema é outro: em primeiro lugar, há que se saber como ela vem sendo "tocada". E, a mesmo tempo, realizar um esforço imenso para planejar um desenvolvimento econômico com o máximo de floresta em pé.

Para tanto, seria preciso criar políticas públicas adequadas para cada uma das células espaciais da região amazônica, e incentivar os poucos modelos de economia ecologicamente "auto-sustentada" criados pelos próprios amazônidas (Projeto Reca - Reflorestamento Econômico Concentrado e Adensado, por exemplo).

Em um ano, perdemos 26 mil km² de florestas biodiversas. Não será a invasão do capitalismo selvagem na Amazônia brasileira que poderá resolver o destino dos vinte milhões de amazônidas ali residentes - uma grande parte vivendo uma geografia humana extremamente sofrida, tanto no mundo urbano em crescimento quanto nas regiões silvestres e rurais.

É lamentável que não se tenha consciência sobre os destinos da Amazônia. Cabe à nossa geração - ao início do século XXI - exigir um gerenciamento mais correto e inteligente para garantir a preservação das biodiversidades e a sobrevivência dos homens e da sociedade no grande Norte brasileiro.

Estudos Avançados - Diante da semelhança entre geógrafos e geólogos no que tange à noção de escala do tempo, da natureza e da escala de tempo da bumanidade, como o sr. vê a escala do século que passou? Gostaria que a avaliação fosse feita com expectativas para o século XXI.

$A z i z$ Ab'Sáber - Vou decepcioná-lo um pouco. Você falou nas escalas de tempo e espaço e, no caso da Amazônia, isso é essencial. O que aconteceu na história geológica da Amazônia brasileira, sobretudo, foi extraordinário em termos de interferências tectônicas e mudanças de tipos de bacias sedimentares. A teoria de placas que procura explicar a junção de África e Brasil tem mais propriedade do que as teorias de derivas antigas, embora a deriva deva ser considerada entre os dois blocos; sendo assim, se é que a teoria de placas pode ser aceita, a depressão amazônica, antes que houvesse qualquer barreira oeste tipo andina, era um golfão, e a presença de sedimentos de várias idades do Paleozóico, Siluriano, Devoniano e Carbonífero e depois muito mais tarde, restos de sedimentos marinhos do Mioceno, em vários lugares, a oeste, um pouquinho a leste, na região da Bragantina, servem para documentar que o mar vinha de oeste até um certo tempo. Nesse caso, o dobramento dos Andes acabou com o golfo, criando um paredão volteado, que nós chamamos de terras cisandinas. De maneira que isto proporcionou o começo de uma sedimentação terrígena flúvio-lacustre muito ampla, que é a que deu origem, dentro do golfão antigo, a grandes territórios para a Formação Alter do Chão: barra, barreiras. Somente a partir dessa sedimentação é que o rio se inverteu - o Amazonas era um rio complicado dentro do gol- 
fão que não era muito homogêneo. Quando os Andes se soerguem, a sedimentação terrígena estende-se de oeste para leste, tamponando velhas formações sedimentares paleomesozóicas do antigo macrogolfo regional (Amazônia ocidental); existe a certeza de que a drenagem amazônica possuía um rumo lesteoeste, na direção do grande golfo regional. Nos fins do Terciário, o paleorio Amazonas, que diferia totalmente do atual, foi tamponado pelas formações sedimentares pliocênicas (Formação Alter do Chão e Formação Barreiras), de forma que o rio Amazonas, tal como o conhecemos hoje, é um curso fluvial hidrologicamente recente, gerado em tempos pós-pliocênicos.

Tais acontecimentos geológicos foram responsáveis por uma drenagem quaternária tipicamente centrípeta na Amazônia ocidental, sob a condicionante ecológica de um domínio clímato-botânico equatorial. A porção brasileira da Amazônia, pelo seu tamanho e extensão, constitui o mais importante megadomínio de natureza tropical da Terra. Na realidade, é um domínio quente e úmido propiciador de uma história vegetal que embrionariamente remonta ao início do período Quaternário. Até o Terciário Médio, comportava-se como um paleogolfão da fachada pacífica do continente, intercalado entre os terrenos do Escudo Guianense e do Escudo Brasileiro norte-oriental. Essa grande inversão forçada pelo dobramento da Cordilheira Andina exige que, antes desse fato, os bordos da Amazônia oriental ainda teriam vínculos com os terrenos antigos da África Ocidental.

Isso me leva a dizer que as escalas de tempo na Amazônia são muito complexas, porque o embasamento cristalino que está do lado das Guianas e do lado do planalto brasileiro setentrional possuiu rochas gnáissicas e graníticas em importantes enclaves (Carajás, Serra do Navio) de rochas metalogênicas (manganês, ferro, entre outros), de antiqüíssimas orogêneses criadas em determinadas situações que hoje não podemos imaginar, visto que o escudo de rochas resistentes sofreu vários soerguimentos epirogênicos acompanhados de sucessivos processos erosivos que acabaram por expor jazidas minerais formadas em grande profundidade, através de muitos contatos de calores extraordinários. E do outro lado há a grande área de manganês que também sugere tempos muito antigos - embora hoje a Serra do Navio esteja reduzida a um buraco. Passei por lá recentemente e é triste verificar que, em pouco tempo, esgotou-se o manganês da região, por uma razão bem simples: interessava ao mundo no momento em que foi descoberto, o mundo não tinha manganês para a indústria siderúrgica e metalúrgica de vários países. Assim, quando se descobriu o manganês na Serra do Navio e se fez um contato entre empresas brasileiras recém-criadas e empresas americanas de grande consolidação com problemas de prospecção e exploração, o mundo recebeu quase todo o manganês da parte das Guianas, mas na parte brasileira ainda sobraram muitas outras riquezas minerais. Na parte, também do sul, onde está Carajás, com grandes reservas de minério de ferro da mais alta qualidade, há, paralelamente, um distrito mineral, provavelmente o último grande distrito mineral descoberto no mundo durante a segunda metade do século XX. 
As idades dos terrenos cristalinos, cristalofianos e os dotados de ferro de um lado e manganês do outro, são muito antigas. Constam, por aproximação, de um bilhão e quinhentos milhões de anos, enquanto os terrenos Devonianos, Silurianos e Carboníferos, que são como depósitos marinhos de fundo de golfo do passado, têm cerca de trezentos milhões de anos. Os terrenos sedimentares desta vasta bacia, formada pelos dobramentos dos sedimentos flúvio-lacrustes, possuem no máximo quinze milhões de anos.

Então, quanto a essa parte das escalas, só posso lhe dizer isso. Mas a sua pergunta essencial é sobre o século XX.

Como estou muito interessado na evolução desse século, gostaria de começar dizendo que o século XX, na Amazônia, começou um pouco antes do ano de 1900, isso porque, de repente, já haviam ocorrido algumas mudanças de atividades na Amazônia, em função do novo olhar de mundo direcionado pelo extrativismo do látex retirado da seringueira: o ciclo da borracha. A ruptura ocorrida no importante ciclo da borracha entre 1910 e 1912 conduziu a região a uma longa e triste estagnação por quase meio século.

A primeira ferrovia cortando as terras firmes por um espaço razoável foi a Bragantina, a qual colocou Belém em contanto com Bragança na região do Salgado, localmente representada por aquelas planícies de mangue que existem desde o noroeste do Maranhão até o nordeste do Pará. Um projeto que foi mais tarde ladeado por estradas de rodagem em uma área em que se pretendia consolidar a vida agrícola nas suas margens, em função da existência de uma tradição de agricultura itinerante.

Logo, a primeira fase onde reconheço mudanças de atividades em espaços um pouco mais amplos foi a da região Bragantina. A segunda fase, que foi a de encontro de certos setores das terras firmes que poderiam receber uma agricultura local de uma certa economicidade, foi a da região de Tomé-Açu.

A experiência dos americanos em Belterra, no vale de Tapajós, é um pouco sincrônica a tudo isso, mas é complicada, porque não deu certo em nada, pelo contrário, criou a idéia de que foi uma excelente contribuição para obter melhores conhecimentos sobre o corte da mata e a regeneração da floresta.

Depois disso tudo, o extrativismo continua muito pálido até 1910 e 1915. E tudo aquilo que o extrativismo legou para a Amazônia durante um século entra em decadência, que é uma decadência de uma geografia humana muito sofrida para os seringueiros, para os beiradeiros de igarapés e também para as cidades. Fui pela primeira vez a Manaus em 1952, quando estava começando um novo ciclo urbano, com a construção de um bom hotel e com o término do aeroporto de Ponta Pelada, que foi o primeiro - hoje ele é um aeroporto apenas militar, devido à decadência comercial extrema da cidade.

Aqui aproveito para deixar registrada a maneira pela qual cheguei à Amazônia, nessa ocasião com os professores Wladimir Besnard, Ari França e o piloto da FAB. 


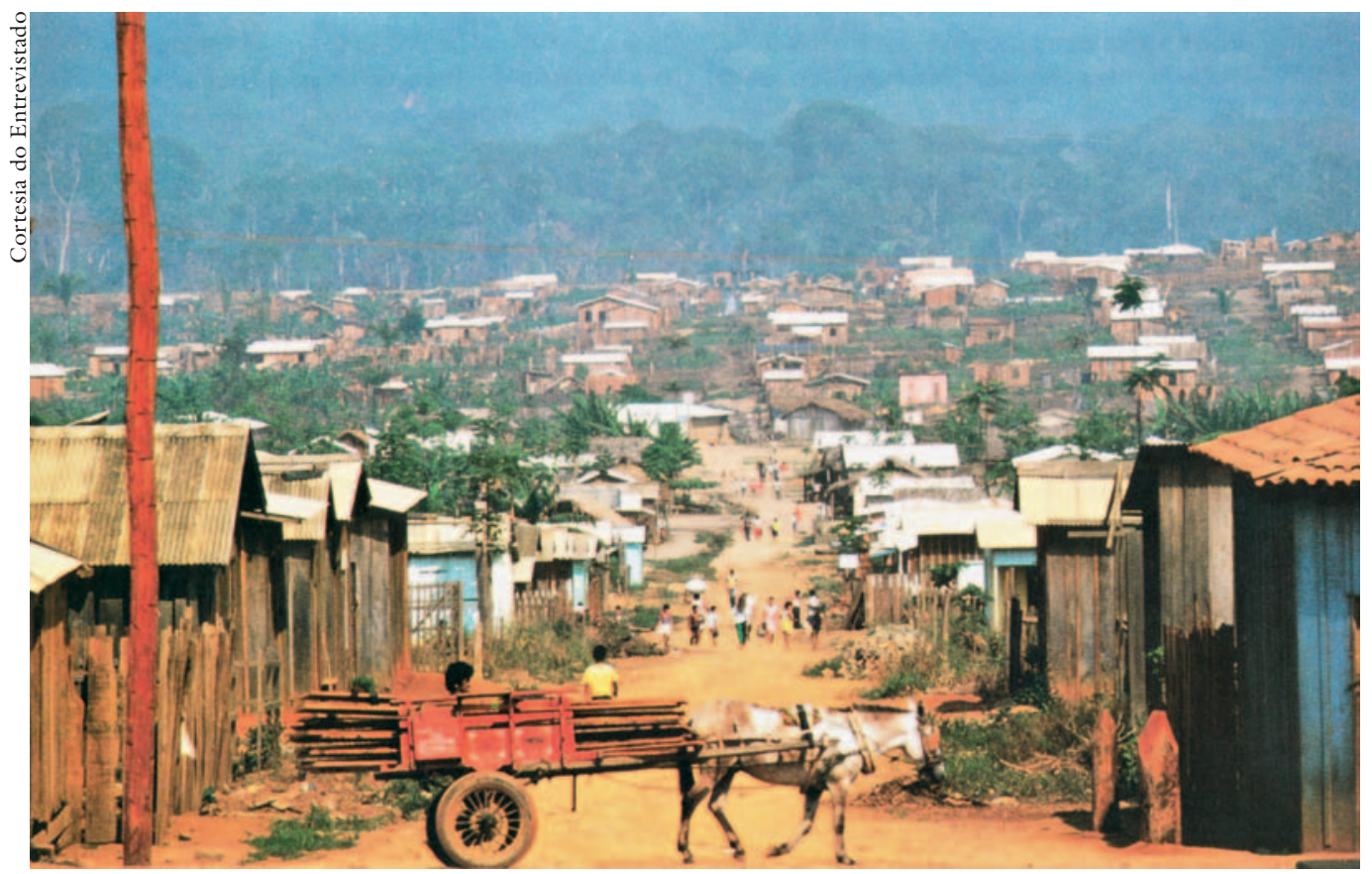

Rio Verde, o núcleo satélite da cidade de Paraupebas.

Como eu era prático em laboratório, não me colocavam em discussões longas e importantes que gostaria de fazer. Então, um dia o professor Ari França chegou no Departamento de Geografia e disse o seguinte: "amanhã vai um avião para a Amazônia. Quem é que se candidata?”. Então fui com o conjunto: um antropólogo, o professor Wladimir Besnard (oceanógrafo), eu e a tripulação.

Essa viagem foi o começo de minhas pesquisas na Amazônia. A sucessão de estudos foi: agricultura itinerante em Bragantina; tentativas fracassadas de fazer plantações de seringueiras dentro de clareiras na mata, numa região de solos inadequados pelos americanos em Belterra, depois Tomé-Açu, e, mais recentemente, toda essa invasão capitalista de que a estrada de Belém-Brasília participou muito, pois à medida que a estrada foi se estabelecendo, começou o apossamento de terrenos no coração das florestas (Pará) e parte dos cerrados (norte de Goiás, atual Tocantins). Note-se que a estrada demorou a ser implantada, pois ela estava cortando extensas áreas florestais. É bom registrar que a Belém-Brasília, ou mais precisamente a Anápoles-Belém, foi construída sem qualquer preocupação de previsão de impactos ecológicos e sociais, infelizmente. As pessoas já começavam a ocupar terras devolutas e laterais, mais perto de Belém, comprando por preços aviltados terras de proprietários que não tinham possibilidade alguma de produzir, tampouco tinham documentos legais de posse. É conveniente saber que após a construção da Belém-Brasília ocorreram modificações nas atividades agrárias da região bragantina, incluindo o cultivo da pimenta e outras coisas mais, bem como algumas tentativas de plantações de seringueiras. Assim, desde as agriculturas itinerantes e o extrativismo, até a agropecuária, tivemos um século de mudanças no espaço total regional. 


\section{Zoneamento, os subespaços da região}

Com vistas à melhoria das condições em processo no imenso espaço territorial da Amazônia brasileira, julgamos ser indispensável conhecer todos os subespaços da região em termos de conjunturas socioeconômicas, e expectativas das comunidades amazônidas residentes, a fim de propor medidas de interesse social e econômico e sistemas de gerenciamento ecológico racionais e inteligentes. A discussão, feita por nós em um trabalho sobre zoneamento ecológico econômico da Amazônia, foi explicitamente dirigida para tais objetivos que deveriam ser projetados para o século XXI na grande região.

Sempre foi muito difícil apresentar a Amazônia, no seu todo espacial e em suas diferentes regiões e quadrantes, a estudantes primários, secundários e para parte dos universitários.

Até meados do século XX, houve notória falta de conscientização das ações sobre o mundo físico e sociocultural da Amazônia brasileira. Razão pela qual os informes de cronistas, viajantes naturalistas, médicos, sanitaristas, missionários, indigenistas, geólogos e intelectuais amazônidas constituíram-se como a base dos conhecimentos disponíveis para um restrito número de leitores. É certo que tais informações fragmentárias setoriais não tiveram possibilidade de chegar aos brasileiros de todo o país.

A condição prévia para entender a Amazônia em seu todo reside em uma setorização abrangente de grande concretude e visibilidade, ou seja, um esforço para regionalizar um megaespaço mal conhecido e mal gerenciado pelos governos que se sucederam no Brasil. A estratégia de um primeiro zoneamento, realizado em células espaciais de indiscutível propriedade, é o primeiro passo para servir a um padrão de desenvolvimento com um máximo de floresta em pé e biodiversidades integradas. A partir de uma setorização em quadrantes da ordem de 80 a 150 mil km, poderão ser feitos detalhamentos minuciosos de cada subregião pré-identificada, utilizando todos os recursos cartográficos, aerofotogramétricos e, sobretudo, a visualização espacial do Projeto Radam e as notáveis imagens de satélite disponíveis.

Ao longo do eixo oeste-leste do vale amazônico, envolvendo as planícies de inundações e os baixos vales dos rios afluentes, podem-se reconhecer cinco setores principais: o alto Solimões e, a partir da confluência com o rio Negro, o médio e o baixo Amazonas e, por fim, o Golfão Marajoara. Para completar a setorização geográfica, há que se considerar, nesses espaços, a presença de alguns pontos nodais: o Projeto Jarí e a área de Macapá-Porto Santana. Ao sul da faixa oeste do Amazonas desdobra-se uma série de regiões geográficas individualizáveis, desde o Acre até a chamada região Bragantina do Pará.

Cada uma das células espaciais amazônicas tem de ser conhecida em sua realidade física, ecológica, urbana e social para a percepção de seus problemas e as expectativas das suas comunidades residentes, sendo necessário fazer estudos metódicos e realistas sobre os pontos nodais como as regiões de Manaus, Belém, 
Paraná do Ramos, Santarém/ Alter do Chão, Jari e Trombetas, Macapá-Porto de Santana, Rio Branco-Xapurí, Marabá-Carajás, Boa Vista-Caracaraí, Porto Velho, Projeto Reca, "Lavrado", as terra florestadas de Roraima, e, finalmente, de alguns setores das fronteiras com Venezuela, Colômbia, Peru, Bolívia e Guiana Francesa.

As linhas de quedas existentes nos confins dos baixos vales afluentes do Amazonas - ao sul e ao norte do grande rio - foram acidentes que dificultaram a circulação hidroviária na Amazônia oriental. Por outro lado, os rios ocidentais da região, sobretudo o Purus e o Juruá, são por demais meândricos, tornando vagarosa e sofrida a navegação fluvial. Por falta de recursos e por pressa, não foi possível construir comportas em Tucuruí para viabilizar o transporte fluvial por um bom trecho do rio Tocantins. Poderá ocorrer o mesmo na região de Volta Grande, no rio Xingu, onde se pretende construir mais uma importante hidrelétrica. Razão pela qual restou como projeto de navegação para médio porte o alongado rio Madeira desde Porto Velho ao Amazonas, Paraná do Ramos e portos do golfão marajoara, opção correta do "Avança Brasil", um projeto governamental que, entretanto, desprezou dezenas de outros quadrantes da grande Amazônia.

Assim, defendemos a tese de que a região tem de ser vista e atendida em todos os setores, por meio de incentivos e atendimentos múltiplos para todas as comunidades residentes. Na Amazônia brasileira projeta-se uma população de vinte milhões de seres humanos, muitos dos quais marginalizados em razão de uma geografia humana sofrida. O mundo urbano novo que fez crescer e multiplicar cidades atraiu gente de todas as beiradas de vio e igarapés, mas não teve força para ampliar ou multiplicar mercados de trabalbo. Dai ter surgido uma nova pobreza, responsável por subnutrição, bairros carentes, favelas e dramas pessoais e familiares inenarráveis.

Estabeleceu-se a importante e competitiva Zona Franca de Manaus, construíram-se represas para hidrelétricas, descobriram-se petróleo e gás na Amazônia ocidental, mas, em compensação, rasgaram-se rodovias em desmesuradas extensões de terras florestadas sem qualquer previsão ou gerenciamento de impactos físicos, ecológicos e socioambientais. Na terra dos grandes espaços florestados, tramou-se contra as reservas indígenas e contra os próprios indígenas, remanescentes da pré-história. Atendeu-se literalmente a todos os interesses dos especuladores de fora e de dentro do país sob alegações de um desenvolvimento que se sabe absolutamente incompleto e anti-social.

Privatizou-se o distrito mineral mais importante descoberto ao longo do século XX (Carajás). Esgotaram-se as jazidas de manganês da antiga Serra do Navio e, após se terem tolerado as pressões dos proprietários de garimpo, não houve estratégia correta para enfrentar a sanha dos madeireiros que continua a existir sob grande pressão. E, assim, a Amazônia, a maior e mais rica floresta tropical do mundo, berço de riquezas incontáveis para a humanidade, por sua biodiversidade, transformou-se num espaço de cobiça e crítica que fere a auto-estima de todos nós. 
Estudos Avançados - A Amazônia, por ser um universo paralelo, faz com que essa porção ainda continue desconbecida na parte sul do pais. Sendo assim, qual é o mecanismo de integração da Amazônia com o restante do país? Será que não há uma percepção totalmente equivocada do sul do país bem como do exterior em relação à Amazônia?

$A z i z A b$ Sáber - São perguntas essenciais do ponto de vista antrópico. Estudo muito as áreas culturais existentes no Brasil como um todo e a conclusão a que tenho chegado é que algumas dessas áreas, por várias razões, inclusive por causa da circulação facilitada, são extremamente ricas.

No caso da Amazônia, a expansão cultural se fez apenas dentro do território, a partir do centro dos rios principais para as periferias, chegando até as fronteiras do Acre, de Roraima e do Amapá. De qualquer maneira, é o conjunto de valores culturais da própria região que se expandiu exclusivamente por ela.

Os outros grupos culturais precisam ser conhecidos, e o mais importante de todos como cultura popular do país é o sertanejo. Sua cultura se incorporou à Amazônia, por causa dos períodos de seca e de migração forçada por vários fatores. A Amazônia tem uma série de raízes indígenas, portuguesas e negróides, porém, tem raízes culturais que não pertencem somente a ela, mas que vieram do nordeste seco. Tenho um colega que um dia pôs uma notinha no rodapé de um trabalho seu dizendo: "os que vinbam do nordeste para a Amazônia gostavam de seguir para as zonas dos seringais, porque eles imaginavam que no fim daqueles rios longos e volteados iriam reencontrar o seu sertão", eu achei maravilhoso isso.

A divisão que faço das principais culturas do Brasil é: amazônida, muito mestiçada culturalmente; sertaneja, dentro da região nordeste seco; a pantaneira, pouco conhecida, pouco estudada, porém de uma realidade diferenciada; a gaúcha; a caiçara e a caipira, em São Paulo já semidestruída, mas com várias emergências em processo de modificação.

A ordem de grandeza do país dificultou, desde há muito tempo, a integração político-administrativa da Amazônia ao Brasil, porque a Amazônia tem um rio oeste-leste que, durante muito tempo, exportava diretamente suas coisas para os outros países do mundo, através de Belém e agora, depois da descoberta do manganês, através de Macapá. Por sua vez, a região do planalto brasileiro (incluindo as caatingas, cerrados, Brasil tropical-atlântico, planaltos das araucárias e pradarias mistas) possui uma trama de ferrovias que começou na década de 1870 e de rodovias que se multiplicou e se aperfeiçoou nos últimos cinqüenta anos, facilitando a circulação de pessoas. Assim, é muito mais fácil encontrar um gaúcho na região pré-amazônica ou no interior da própria Amazônia, que comprou pedaços de terras para fazer suas fazendas, do que encontrar humildes amazônidas em regiões do centro-sul brasileiro.

Mas o pior de tudo é que nem o amazônida semilocalizado em certos setores entende a Amazônia; ele se deixa, inclusive, iludir pela modificação de 
atividades. Os primeiros eram os que foram cortar madeira para a construção da estrada Belém-Brasília - conforme disse o professor Orlando Valverde: "foi uma legião de machadeiros", mas logo depois vem a fase de expansão das agropecuárias, perto das estradas e medianamente longe das selvas, trazendo consigo a motosserra que facilitou a predação e continuou como sistema único, a fim de preparar o terreno para a agricultura ou a pecuária, de modo que, conseqüentemente, passaram a lavrar queimadas por toda parte.

Estive uma vez nos arredores de Belém e uma instituição importante tinha derrubado um pouco de mato para fazer qualquer atividade lá, estavam queimando para fazer algumas experiências agronômicas. Então eu perguntei: "mas vocês estão seguindo o mesmo rumo dos outros?", aí eles disseram que era a única maneira econômica de conseguir um espaço exposto para atividades dentro das florestas contínuas da região.

Na Amazônia, no fim do século XX, o processo de desmatamento para encontrar terras suficientes para atividades agropecuárias lembra o mesmo caso da colonização portuguesa na parte atlântica na zona da mata nordestina. E, curiosamente, os grandes tropicalistas franceses que deram aula nessa nossa universidade diziam que era uma coisa absolutamente normal: para encontrar espaços para agricultura é necessário cortar a floresta, sem nenhuma indicação de planejador, apenas dando o aval teórico para isso. E é exatamente isso o que irrita, porque ou a gente passa a encontrar alguns tipos de atividades que sejam economicamente auto-sustentáveis (eu não uso a palavra "sustentável" nunca, a não ser para economia ecologicamente auto-sustentável, e esse é o caso que estou defendendo para o entorno das flonas - florestas nacionais). Ataco as flonas e os asseclas do meio ambiente que querem conseguir flonas para ONGs, ou então alugar flonas para obter dinheiro, que não é tarefa específica do Ministério do Meio Ambiente.

\section{Reca, um bom projeto}

Sugiro então que se faça o uso das bordas dessas florestas que estão mais ou menos bem preservadas para atividades agrárias auto-sustentáveis. Por exemplo, lá nos confins de Rondônia, na fronteira com o Acre, um ex-padre francês, que veio com uma garra enorme, porque tinha origem rural e queria dar um jeito de servir à Amazônia, começou a conversar com Dom Grechi, lá de Rio Branco, e passou a associar-se com o pessoal de uma zona rural de uma cidadezinha próxima à fronteira, Senador Guiomard, que é a única que tinha plantações economicamente válidas, mas muito pequenas, de maneira que graças ao contato com os parceiros amazônidas do Acre pôde inventar a ocupação de "bordo de floresta”.

Tem grande interesse na conjuntura atual da Amazônia saber que os bordos de floresta, recuados por ações antrópicas, têm uma importância ecológica muito grande, devido à umidade remanescente combinada com a luminosidade confrontante. Um fato que possibilitou o início do projeto Reca na fronteira do 
Acre com Rondônia, modelo que pode ser ampliado para as mais diversas áreas de terra firme amazônica. O objetivo dos que fizeram esse modelo de economia silvoagrária auto-sustentada era o de aproveitar áreas já devastadas a partir do bordo da floresta, sem mexer muito com o interior da mata e sua biodiversidade, impedindo assim a penetração dos habituais especuladores insensíveis, corrigindo os solos e desdobrando atividades, envolvendo espécies amazônicas (açaí, cupuaçu, pupunha e castanheiras) e outros cultivos (mandioca, abacaxi, mamoeiros, cana-de-açúcar e bananeiras). Desse modo, dentro da floresta apenas continuaria o extrativismo da seringueira e a coleta dos ouriços da castanha. Nos bordos da floresta, engendrou-se uma forma de plantar para alimentar, nos primeiros dois anos, as pessoas que trabalhavam e depois, à custa de outros processos agronômicos, plantaram-se açaí, pupunha e cupuaçu, para atividades rentáveis para os quatro, cinco anos posteriores. Aí perguntei a eles: "como é que vão esperar que as castanheiras cresçam, visto que demoram dezessete a dezoito anos?" Eles me responderam que, para o primeiro ano, tinham o abacaxi, as hortaliças e o extrativismo em continuação, por isso mesmo "quem quiser entrar em nossa cooperativa, deve ficar por dois anos para conhecer e estudar. Então fazemos plantações de ciclo curto para poder nos alimentar no ano corrente e, a partir de dois anos, nós teremos reservas". As plantações eram de abacaxi, hortaliças, mandioca e um pouco de feijão; logo nos primeiros tempos eles começaram a fazer uma pequena indústria, esquentando a castanha que, depois, as mulheres, em mesas rústicas, quebravam e empacotavam vendendo para várias partes do mundo.

Pelo que pudemos observar em diversas regiões pode-se, nos bordos da floresta, plantar bananeira, depois açai, cupuaçu, mandioca e mamoeiro, além de outras coisas mais. Esta é, portanto, a unica proposta que ofereço para se ocupar os bordos de qualquer floresta, sejam eles de terras devolutas mal trabalbadas, ou de proprietários mais esclarecidos.

Escrevi na penúltima sessão da Scientific America uma proposta desse tipo apoiada nos trabalhos desenvolvidos pelo ex-padre francês, sugerindo que para as flonas fosse adotado o mesmo procedimento.

\section{Flonas, um projeto desastroso}

O assunto florestas nacionais é muito mais delicado e complicado do que geralmente se pensa na mídia. Quando se estabeleceu no conjunto das unidades de conservação da Amazônia, a expressão flonas tinha um certo endereço, ainda que muito vago. Imaginava-se que no entremeio de grandes extensões de ecossistemas florestais presumivelmente bem conservados deveriam existir alguns setores que, em algum tempo, pudessem receber um tratamento econômico diferenciado.

Com o tempo, as áreas extensivas de vegetação florestal foram devastadas por numerosos fazendeiros e pecuaristas totalmente insensíveis às preservações das biodiversidades regionais. E, assim, as flonas sobraram até o início do século XXI com extraordinárias manchas florestais, dotadas de ecossistemas primários. 
De repente, alguns pretensiosos defensores da natureza resolveram pressionar o governo central no sentido de se concederem flonas para as ONGs estrangeiras e aluguel para empresas interessadas na exploração de madeiras nobres. O ponto, porém, é que as ONGs estrangeiras não têm capacidade alguma para exercer atividades econômicas ditas auto-sustentadas, muito menos as empresas madeireiras, que têm condições de alugar florestas por trinta ou sessenta anos com vistas à realização de um desenvolvimento sustentável. Paradoxalmente, os que hasteavam a bandeira das matas atlânticas passaram a defender o ideário do aluguel das flonas para especuladores reconhecidos.

Contrapondo-se à SOS Mata Atlântica, defendeu-se a liberação de importantes trechos da floresta Amazônica para particulares por longo período de tempo, situação esta bastante antiética, em face das possibilidades de mudanças racionais para governantes que se sucederem. Trata-se de uma iniciativa lamentável, capaz de agressões e assaltos em relação a áreas que, por motivos eventuais, são remanescentes de vegetação florestal biodiversa.

\section{Discordamos totalmente da alta diveção do Meio Ambiente sobve essa flexibilização impensada de processos contra os ecossistemas florestais altamente biodiversos de nossa Amazônia.}

Existe um certo consenso de que os que fazem críticas severas a projetos elaborados por técnicos e pseudotécnicos de governo devem apresentar alternativas. Outros julgam, entretanto, que cabe aos governadores reconhecer os erros de seus incompetentes "planejadores" e, de sua própria iniciativa, à custa de outros pesquisadores, encontrar alternativas para (re)direcionar projetos. Ao nosso ver, a busca por novas alternativas deveria ser realizada com o intermédio de cidadãos esclarecidos.

A partir do ideário primário das reservas extrativistas, que em certo momento encantou o mundo com a garra de Chico Mendes na guerrilha dos "empates", podem ser feitos acréscimos notáveis e socialmente rentáveis com projetos híbridos e inteligentes introduzidos pelos acreanos na fronteira com a Rondônia (Nova Califórnia).

Na presente sugestão alternativa está a idéia de desenvolvimento socioeconômico com o máximo da floresta em pé e de proteção possível para a biodiversidade regional. É um esquema que protegeria o corpo integrado do ecossistema florestal, desenvolvendo atividades agrárias e eventualmente silvestres na borda das matas, aproveitando o conjunto de fatores favoráveis: umidade derivada dos "cabelos" da floresta, sombreamento diurno flutuante, luminosidade e taxa de calor. Para tanto, há que progredir no avanço de espécies de interesse para alimentação familiar e agronegócios complementares. Entre as culturas de ciclo curto, a mandioca é a mais importante. Pode-se iniciar o cultivo nos retalhos da borda da mata e, depois, ampliá-los para melhoramento do solo já degradado. Da mesma forma, a castanheira deve ser plantada nos retalhos mais alterados das rebordas das flonas. 
Falta prever e detalhar muitas implantações indispensáveis: escolas de ensino fundamental, ramais e pequenas estradas para o transporte da produção. Nada impede que, de modo complementar, seja possível continuar o extrativismo no coração da floresta, concentrando-se no látex e na coleta de ouriços da castanha. Mas será sempre na periferia das flonas que o desenvolvimento socioeconômico e cultural poderá constituir um dos melhores exemplos de "economia ecologicamente auto-sustentada”.

Como já se disse: para os dias de hoje queremos a plantação de mandioca e cereais; em cinco ou seis anos, o açaí e o cupuaçu; as castanheiras ficarão para nossos filhos e netos; agora, vamos continuar o extrativismo, enquanto tudo estiver crescendo nas beiras das florestas. Ignorantes são os proprietários vindos de longe, que nada sabem fazer de prático. Assim falou o amazônida, que merece governantes mais sensíveis e fazendeiros menos arrogantes e agressivos.

Muitas meditações e idéias ainda deverão ser feitas para salvar florestas e ajudar representantes de uma geografia humana sofrida. Cabe a todos os que conhecem a Amazônia trabalhar um pouco mais, com inteligência, dedicação e ética. Por último, queremos registrar - para todo o sempre - que consideramos um crime histórico a idéia absurda de alugar as flonas para empresas exploradoras de madeira e outras espécies da biota vegetal regional. Quanto à idéia de conceder o gerenciamento das mesmas para ONGs estrangeiras que desconhecem os problemas da Amazônia, não queremos nem falar, pelo absurdo entranhado nessa sugestão.

O problema do crescimento de proprietários é muito sério. Saindo de Rio Branco com alunos da Universidade Federal do Acre, parei num restaurante para tomar um refrigerante, quando um senhor ficou assustadíssimo de ver aquele grupo de jovens. Começou então a reclamar por detrás de uma cortina de tapetes: "esses paulistas vêm aqui para explorar nossa terra". Isso nos mostra a repetição de um mesmo erro que cometemos ao chamar todos os nordestinos de "baianos", no aspecto pejorativo. Lá é o contrário, é "o paulista que não presta". Quando paramos no segundo restaurante, tive oportunidade de questionar com o dono do porquê de tanto ódio aos que vêm de fora, então me foi dito que era por causa da ignorância, visto que, se fosse permitido fazer parceria na terra que eles conquistaram, nós iríamos produzir muitas coisas rentáveis para eles como, por exemplo, a exploração das seringueiras e a catação dos ouriços de castanhas. Tal depoimento mostra que eles ainda não conheciam o projeto do plantio dos bordos da floresta.

Estudos Avançados - O professor acha que esses projetos são capazes de reverter os processos de ocupação histórica da terra no Brasil pela pecuária na Amazônia?

$A z i z A b$ Sáber - Não acho possível, diante do que conheço dos pecuaristas e até mesmo dentro do MST e de qualquer opinião de ambientalista ou de planejador. 


\section{Estudos Avançados - E qualé o cenário então?}

$A z i z A b ’$ Sáber - É um cenário muito negativo. Se o governo não tomar algumas providências de planejamento e fomentar projetos tais como o do expadre (que ficou conhecido como Reca - Reflorestamento Econômico Concentrado e Adensado), não haverá mudanças significativas. Assim, em se tratando das bordas de floresta no conjunto de terras baixas da Amazônia que estão em processo de devastação e que têm sempre um paredão de bordo de floresta, não há outra solução: ou o governo incentiva os fazendeiros a fazerem parcerias, ou não haverá alternativa. Quanto às planícies, é evitar a chegada da grande agropecuária, porque os seus moradores sabem muito bem como produzir ali, sabem se defender das cheias, com adaptações nas habitações e no plantio das hortaliças, por exemplo, porém revelando ser uma geografia humana tradicional sofrida. Um dos exemplos é o problema da escola primária, com muitas professoras leigas, sendo necessário buscar pessoas de muito longe para ensinar.

Queria lembrar a vocês que existe uma delicada questão nesses últimos trinta anos entre o ideário das reservas extrativistas e o do projeto Reca. Se falarmos para pessoas que são discípulas de Chico Mendes que o projeto Reca é superior ao do de reservas extrativistas, elas ficarão malucas, por conta de seus ideários e da extraordinária reverência que há pela memória de Chico Mendes. Elas não perceberam que o projeto Reca é um acréscimo extraordinário às reservas extrativistas a partir da borda da reserva. Por isso, não é possível falar com as pessoas que são herdeiras de Chico Mendes, não dá, por exemplo, para falar com a Marina Silva sobre isso; aliás, entre vários atos falhos da Marina, temos a concessão de flonas para ONGs estrangeiras, sob a alegação de que iria evitar os desmates contínuos que estavam ocorrendo, porque desse modo, o particular iria fazer o gerenciamento e a fiscalização. Da mesma maneira, é o aluguel de floresta para a exploração de espécies nobres de madeira. Na realidade, existe outra coisa que me deixa positivamente chateado com o Capobianco e com a Marina, pois para eles toda e qualquer floresta nacional, com $2.500 \mathrm{~km}$, tem a mesma estrutura de espécies não contínuas dentro do corpo geral da floresta.

Assim, para se tirar um tronco que esteja a quinhentos metros da borda é até relativamente fácil. Primeiro vai o mateiro, que descobrirá onde está a árvore, depois vai a pessoa que faz a trilha, em seguida vão os motosserristas para cortar a madeira, depois é providenciado o transporte. E quanto às madeiras que estão a quilômetros da borda? Infelizmente, há que se fazer trilhas e caminhos, sendo que os que alugaram a floresta não terão dúvidas, sendo certo que vão "furungar" toda a floresta para transportar os grandes troncos das espécies arbóreas consideradas como madeira nobre. É a mesma coisa quanto aos pedágios aqui: alugamse para poder ganhar dinheiro e, por isso, agora são eles que procuram determinar o aumento do custo do pedágio. Está havendo uma guerra agora sobre isto e a maior será lá, dentro das florestas. É preciso que as pessoas possam prever os impactos ocasionados por aluguéis de exploração de madeira dentro da floresta. 
Estudos Avançados - O que é feito em relação a uma politica de aproveitamento de recursos hidricos da Amazônia, com a possibilidade de desenvolvimento na navegação, tanto de população como de produtos?

Aziz Ab'Sáber - Eu conheci a Usina de Samuel, Balbina, Tucuruí e algumas pequenas usinas que não têm muito significado para uma questão crítica. Evidentemente, houve uma pressão internacional para barragens a favor da produção energética. Um grande planejador americano que se empenhava por vários projetos no mundo, inclusive na Amazônia, queria barrar o próprio rio Amazonas para concentrar suas águas, aumentar sua profundidade e, com isso, adentrar mais para o interior da floresta e chegar a regiões que tinham minério.

$\mathrm{Na}$ época dos militares, os planos foram duplos: integração da Amazônia e aproveitamento hidroelétrico. Numa excursão ao Pará encomendada pelo Ministério de Desenvolvimento Regional, estudamos Bragantina e outros lugares que pudessem receber colonos japoneses para poderem repetir em vários lugares o mesmo sucesso que já havia ocorrido em Tomé-Açu. Em função dessas viagens, pude perceber a questão da fall line, que havia sido registrada pela primeira vez por Pedro Moura, geógrafo, que percebeu que nas embocaduras dos grandes rios Tocantins, Xingu e Tapajós havia uma espécie de região afogada, a qual o professor Francis Ruellan chamou de rias de água doce, paralela às verdadeiras rias que são da área costeira. Percebemos a existência de uma linha de queda onde, de repente, essas áreas de alagamento principal param em frente de uma cachoeira, em Tucuruí, em Volta Grande e em outros lugares mais acima do Tapajós etc. Assim, pude falar para o coronel Passarinho sobre a fall line, e é curioso que ele desconhecia isso, porque falar em coisas novas naquela realidade amazônica era completamente desconhecido.

É por isso que muitos dos planos rodoviários da Amazônia foram feitos sem conhecimento prévio da realidade da região que seria atravessada. Tanto que cheguei a mencionar que seria bom que houvesse uma estrada que ligasse esses três pontos da fall line, porque assim, onde parassem a penetração e a circulação fluvial, poderia se ter uma pequena circulação rodoviária. Eu, particularmente, me penitencio profundamente por isso, porque foi isso que mais tarde ocorreu com a Transamazônica. Então é possível perceber que a estrada essencial que ligava o restante do Brasil a Belém do Pará, onde ficava o ponto terminal da circulação do envio de riquezas, era uma necessidade. Não dá para comparar, no entanto, os problemas criados pela Belém-Brasília, que foram muitos, com aqueles criados pela Transamazônica. E aí surge outro problema que ainda não tratamos, que é a questão dos oleodutos.

Fomos procurados pela Petrobras para ir até Carauari e de lá seguir até Orocum para conhecer os problemas de exploração de petróleo na Amazônia ocidental. No começo eles haviam encontrado muito gás, depois, passaram a encontrar também óleo, tendo surgido então a questão de como transportá-lo para a usina de Manaus. Então nós, que conhecíamos todos os defeitos da malha 
rodoviária da região, procuramos evitar que se fizesse outro rasgão na floresta. Eles entenderam do que se tratava, visto que eram pessoas esclarecidas e, sendo assim, acabaram fazendo uma espécie de bizarria. Construíram oleodutos até o rio Tefé e, para isso, instalaram verdadeiros tanques gigantes, de modo que o óleo todo saía dos oleodutos até lá e, em seguida, descia em balsas até Tefé para o meio do Solimões, onde seguia em um navio velho reparado com grandes porões. O óleo era passado então para outros navios chamados de aliviadores, que o levavam para as refinarias Reman. Entretanto, o tipo de óleo que conseguiram das formações paleozóicas, por vários tipos de estruturas geológicas complexas, era fino igual ao diesel, que não interessava tanto para Manaus e, por isso, passaram a vender o óleo fino para a região leste do Brasil e a comprar óleo grosso da Venezuela.

Estudos Avançados - Como o sr. vê, fora todos esses rasgões, a questão da importância estratégica da Amazônia e da militarização da área?

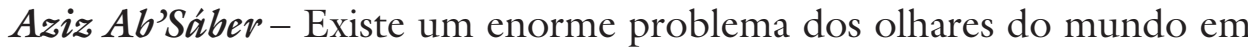
relação à Amazônia. Há duas maneiras de se observar a Amazônia de fora: uma é a exigência da preservação da biodiversidade em termos do possível, que se trata do máximo de desenvolvimento com a floresta em pé - hoje eu diria com um máximo de biodiversidade integrada no interior das matas remanescentes, através de projetos ecologicamente auto-sustentáveis nas poucas áreas que já sofreram devastação, como é o caso do projeto Reca e das flonas -, e a outra é uma maneira insidiosa de separar a Amazônia do resto do Brasil em pleno início do terceiro milênio para favorecer a dominação externa. Esse olhar maldoso contra a soberania brasileira é que nos preocupa, porque depois da invasão do Iraque por causa do petróleo, a tentativa de enquadrar a Amazônia por processos indiretos é muito séria, é muito grave. Porque está na ótica desses especuladores da pseudoglobalização o plano de ter recursos hídricos que estão faltando. Depois dos recursos hídricos, os recursos minerais que já foram comprovados com a questão da Serra do Navio e da Serra dos Carajás, as quais receberam privatizações absurdas.

É necessário lembrar que existiram colônias de exploração, de enraizamento, estratégicas e de enquadramento. Este último caso foi o da Índia, que recebeu um enquadramento bélico e burocrático por parte de ingleses em expansão pelo mundo. É conveniente lembrar que na tipologia histórica das colonizações aconteceram muitas diferenças de comportamento. Tememos boje que esteja em grande expansão o ideário do Primeiro Mundo divigido para colônias financeivas e burocráticas.

O mundo em face dessa cobiça nutrida por países como o Brasil, mas, sobretudo pela Amazônia, a fim de fazer um tipo novo de colônia de enquadramento visando a aproveitar seus recursos naturais silvestres, minerais e hídricos.

Com respeito à militarização, o que preocupa são os países hegemônicos, por vários motivos. Talvez por causa da grande expressão que os países andinos do extremo norte têm em relação aos países do hemisfério norte, estes procuram 
se aproveitar do fato de controlar os espaços produtores de drogas na Colômbia e Peru a despeito da reação da Venezuela.

O certo é que o Brasil percebeu que era preciso colocar uma rede de militarização e de controle dentro da Amazônia. Para isso, previamente, se propôs o projeto Sivam, instalações pré-fronteiriças de agrupamentos militares. Note-se que alguns menos esclarecidos sugeriram fazer uma estrada pela linha de fronteiras, um projeto que seria mais do que criminoso, suficiente para desdobrar conflitos e facilitar interpenetrações indesejadas.

Ninguém pode avaliar o que seja a colocação de grupos humanos de um só gênero no ambiente singelo de distantes cidades amazônicas, como é o caso de São Gabriel da Cachoeira.

As pequenas histórias que conheço a partir de minhas viagens facilitam-me muito entender certas coisas mais amplas. Encontrei um ex-aluno que possuía uma fazenda em Roraima (muito provavelmente dentro das terras dos índios Ianomamis) e então perguntei-lhe como gerenciava o problema com os índios, e me foi dito: "ora, não tem nenhum problema. Para eles o meu capataz apresenta o seu facão". O que quer dizer que há uma séria preocupação quanto a esses "paulistas" que são insensíveis cultural e ecologicamente, porque simplesmente não existe nenhuma ética em relação ao futuro no Brasil, quer no interior dos governos, quer no interior dos ruralistas e madeireiros.

Numa outra ocasião fui a Marabá a convite do Ibama para uma reunião na qual estariam mulheres catadoras de côco e outras pessoas que fazem atividades muito simples, com rendimento muito pequeno. Minha palestra era no segundo dia e, para chegar lá, tinha que transpor uma ponte sobre o rio Itacuinas. Como haveria uma passseata e eu não conseguiria chegar ao local combinado pela palestra, disseram-me para sair bem cedo do meu hotel. Por estar muito cansado, acabei saindo às oito horas, então cheguei onde a transamazônica é uma avenida na cidade de Marabá, e havia mil e quinhentos fazendeiros, capatazes e senhoras de fazendeiros fazendo uma carreata que passava pela Transamazônica em nome do ruralismo deles. A cidade se manteve de "barba quieta", só um ou outro menino com suas bicicletas paravam para ver, então eu parei ali e fiquei meditando sobre o porquê dessa passeata agigantada. Era para dizer que estavam presentes e não aceitariam nenhuma consideração ao MST, ou a projetos colonizadores de gente que não fossem deles mesmos. Eu fiquei absolutamente espantado com a petulância de tudo aquilo.

No caso de Roraima, desde há muito tempo existe o argumento de que há muita terra para tão poucos índios. Nessas regiões conheço dois itinerários. Saí de Boa Vista até Santa Helena na Venezuela, transitando com dificuldade dentro de uma jardineira na presença de garimpeiros brasileiros que iam trabalhar lá. Essa estrada atravessa centenas de quilômetros do lavrado, as paisagens campestres com aquelas belíssimas florestas de galerias cheias de buritizais. Porém, o solo é ruim, não dá para a agricultura. Então pude conhecer algo extraordinário 
na borda da mata quando cheguei em BV8, ainda perto do planalto das Guianas. Tive que dormir num bar-restaurante porque não havia pousada nem hotel; percebi que o dono do bar era também militar e pedi a ele que me desse uma carona até Boa Vista; quando chegou à primeira ponte, ele desceu e disse que iria ver o seu garimpeiro - ele tinha garimpeiros trabalhando a seu serviço, de modo que fui percebendo como funcionavam as coisas por ali.

Mais tarde fui de Boa Vista até as antigas repúblicas comunitárias das Guianas através da cidade de Bonfim. Nessa região, dali para o norte até as primeiras serras florestadas dos bordos do planalto, existem cerrados muito pobres, e as famosas áreas indígenas da Raposa e Serra do Sol. A pretensão dos fazendeiros e administradores municipais em relação à reserva regional de indígenas é imensa; visando a fragmentar o continuum da reserva, instalaram novos pequenos municípios no seu interior, de maneira que fosse necessária a constituição de uma prefeitura com vereadores, que certamente iriam permitir tudo o que os fazendeiros desejassem. É um enclave planejado para a conquista do território indígena, o que criou um problema extremamente controverso e de difícil solução, capaz de atiçar conflitos e posturas demográficas e culturais.

Os governadores de Roraima têm sido muito ruins com os indígenas (para não dizer criminosos) porque fazem todas as bizarrias possíveis para conquistar o espaço florestado e os bordos do lavrado. O governo federal fez uma faixa de colonização entre o lavrado e as florestas serranas; assim, quando houve aquela grande queimada em Roraima, os governantes diziam o seguinte: “onde já se viu, nós demos terras para os indígenas e as terrinhas que demos para os assentados vão sofrer improdutividade por causa das queimadas, é necessário se preocupar com eles". Mas eu, juntamente com o Lula, dei uma volta de avião pela área da mata ao sudoeste, que precede as matas serranas e vi a fumaça saindo de dentro do chão da floresta e passando pelo dossel das árvores. Então pudemos observar uma grande devastação causada por esses fazendeiros e que por isso colocavam fogo e foi esse mesmo fogo que se expandiu pelo lavrado. Infelizmente, nessa época seca, o lavrado tem uma fácil expansão da queimada - embora não entre linearmente na mata de galeria.

Mais tarde, sete ou oito jornalistas estrangeiros perguntaram-me se o local se tornaria um deserto, eu disse que não, mesmo o ar estando impregnado de argueiros das queimadas até a altura da troposfera. Por haver nos céus da Amazônia dois ou três andares de nuvens, quando o nosso avião passou por cima daquela troposfera totalmente enegrecida pude ver que já havia nuvens um pouco carregadas, de maneira que quando chovesse acabariam as queimadas. E esses locais, sobretudo os de campestres e cerradinhos, seriam como a fênix que surge das cinzas, de forma similar seria o ressurgimento da vegetação que brotaria da terra queimada.

Assim, quinze dias depois, veio a chuva e acabou com tudo aquilo e Roraima teve um pouco de estabilidade. Uma professora de uma Universidade Federal 
disse-me que não estava preocupada com as queimadas, visto que o problema maior viria depois, no fim do processo de secura pronunciada, quando a problemática do uso econômico das terras de pequenos colonos surge com mais força. Ela estava correta.

\title{
Trajetória de um pesquisador incansável
}

\begin{abstract}
A ziz Nacib Ab'Sáber nasceu em 1924, na cidade de São Luiz do Paraitinga, A situada no Vale do Paraíba. Entrou na Universidade de São Paulo e formou-se em Geografia e História em 1944, fazendo sua especialização em geomorfologia. Como professor lecionou em diversas faculdades e por catorze anos foi titular na USP.
\end{abstract}

Paralelamente aos seus estudos, Aziz fez inúmeras viagens pelo Brasil, observando a fisionomia das paisagens e as características de cada ecossistema. A busca por compreender a compartimentação total do relevo brasileiro ampliou-se com seu interesse pela fitogeografia, que o levou a investigar a distribuição da vegetação nos diferentes domínios de natureza. Com o tempo, sua abordagem foi se ampliando cada vez mais, integrando as diversas áreas do conhecimento.

A presença de geógrafos franceses no Brasil foi muito importante para a forrmação de Ab'Sáber. A experiência junto a mestres como Jean Tricart, Emanuel De Martonne e Francis Ruellan proporcionou-lhe o contato com um novo universo dentro da ciência. Essa influência ajudou-o a desenvolver uma abordagem mais completa dos processos geomorfológicos, aprofundando-se em três principais aspectos: compartimentação do relevo, estrutura superficial e fisiologia da paisagem.

As considerações de Tricart sobre linhas de pedra no solo (stone lines), que indicariam climas mais secos no passado, foram fundamentais para que Aziz formulasse a Teoria dos Redutos em 1960, e, em parceria com Paulo Vanzolini, a Teoria dos Refúgios, em 1970.

Ab'Sáber participou de muitos congressos, assembléias, simpósios, conferiu palestras e ministrou cursos. Sua contribuição foi decisiva em diversas instituições, assumindo cargos importantes, como a direção do Instituto de Geografia da USP, de 1969 a 1983, e a presidência do Condephaat (Conselho de Defesa do Patrimônio Histórico, Artístico, Arqueológico e Turístico do estado de São Paulo), entre 1982 e 1983, onde trabalhou para que importantes áreas naturais fossem definitivamente tombadas, como no caso da Serra do Mar. Foi presidente da Sociedade Brasileira para o Progresso da Ciência (SBPC) de julho de 1993 a julho de 1995, atuando em prol do desenvolvimento da ciência e da tecnologia no Brasil.

Quando deixou de lecionar na USP, em 1982, passou a se dedicar a pesquisas regionais e a trabalhos com questões ambientais, avaliando impactos físicos, 
ecológicos e sociais provocados por projetos desenvolvimentistas em todo o país.

A integração entre ciência e política é um propósito fundamental para Ab'Sáber. Ele afirma a importância do conhecimento científico para o planejamento e a administração pública, defendendo que a crítica deve ser acompanhada por propostas viáveis e inteligentes.

Desde 1988 integra o Instituto de Estudos Avançados da USP, onde recebeu o título de professor honorário. Nessa instituição, publicou trabalhos relevantes como: "Zoneamento ecológico e econômico da Amazônia: questões de escala e método" (1989); “Um plano diferencial para o Brasil, projeto Floram" (1990); e "Sertões e sertanejos: uma geografia humana sofrida" (2003).

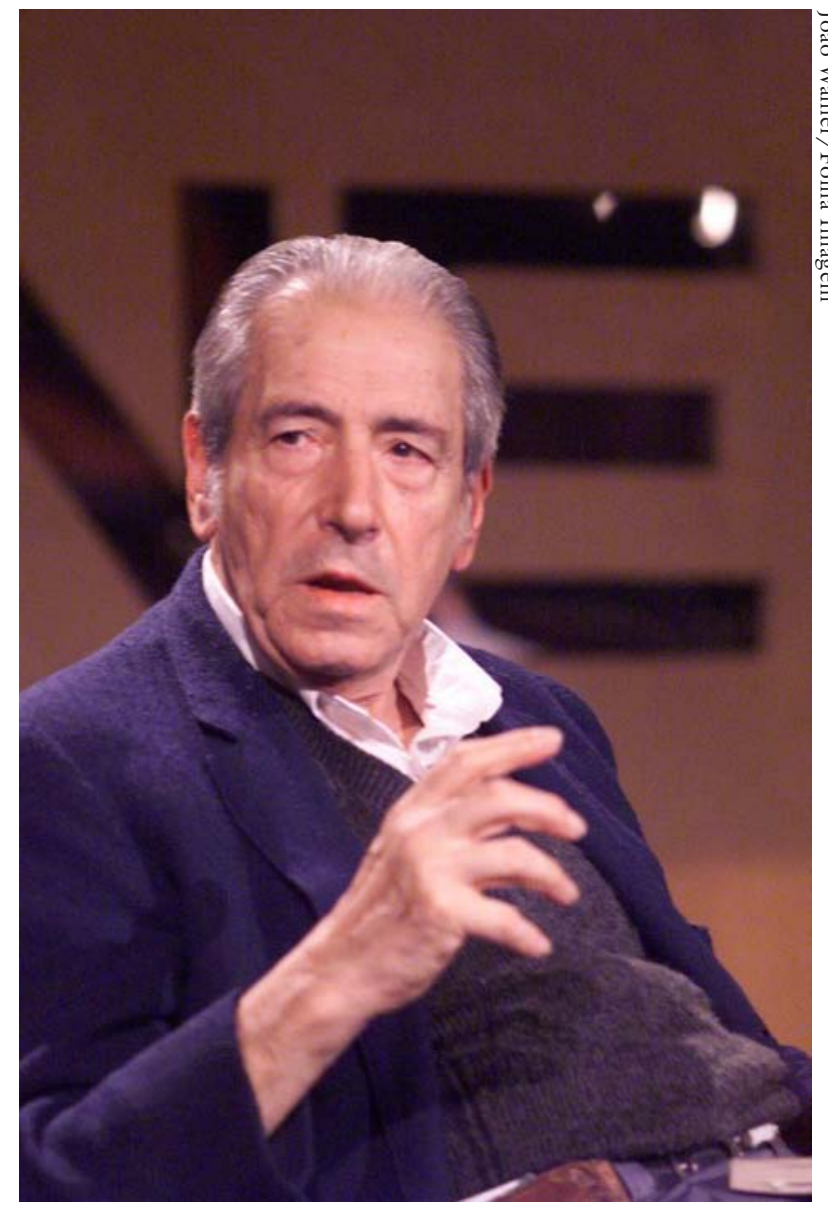

O professor Aziz Ab'Sáber

As pesquisas desse geógrafo foram divulgadas em mais de trezentas publicações. Entre seus principais livros pode-se ressaltar: Amazônia, do discurso à práxis (1997), pelo qual recebeu o prêmio Jabuti; Litoral do Brasil (2001) e Os dominios de natureza do Brasil: potencialidades paisagísticas (2004).

Esses são alguns destaques de toda uma vida dedicada ao conhecimento, uma trajetória que resultou em uma obra de valor inestimável. Profundo conhecedor da realidade brasileira, Aziz Ab'Sáber sempre lutou pela preservação dos ecossistemas e pela criação de uma sociedade cada vez mais justa. 